\title{
Preface to English Edition
}

The original, Japanese edition of this book was published in 1988. A few years later, in 1993, the rule of the Liberal Democratic Party (LDP), which had been in power since its creation in I95s, came to an end. Japan entered a period of political turmoil, in which it became extremely difficult to predict which party would hold power. Some background on this turmoil is important for understanding the passage of new measures affecting local government in 1995.

The fall of the LDP led to the birth of the administration of Morihiro Hosokawa, an epoch-making event in Japanese politics. Hosokawa's power base included the Socialist Party and Komeitō (Clean Government Party), as well as the newly organized Nihon Shintō (Japan New Party), Sakigake Party, and Shinseito (Renewal Party), which had broken off from the LDP. Underlying this political change was the public's increasing tolerance of the Socialist Party, owing to the end of the cold war, and also its growing discontent with the LDP. LDP governments had long favored rural interests while neglecting the interests of urban consumers, and the public's dissatisfaction resembled a time bomb, which finally exploded in the wake of numerous scandals involving party finance.

Party reorganization had only started when the Hosokawa administration took office. Centrist elements supporting the cabinet consolidated into the New Frontier Party (Shinshintō), but their coalition with the Socialists was to be short-lived. The two sides took opposing stances on basic issues, including constitutional reform. Prime Minister Tsutomu Hata's New Frontier Party administration, which followed the 
Hosokawa administration, collapsed when the Socialists left the ruling coalition. The LDP then joined forces with the Socialists and the Sakigake Party, and together they created a cabinet under Socialist Party chairman Tomiichi Murayama. The Socialists steadily retreated from their earlier policy positions during their participation in the coalition government. For example, they withdrew their long-standing opposition to the U.S.-Japan Security Treaty system and moderated their position on Article 9 (the antiwar clause) of the constitution. The issues facing Japanese politicians during the Murayama administration were a faltering economy, the damage caused by the great Hanshin earthquake, social unease following the terrorist violence of the AUM Shinrikyō religious sect, and the problem of bad loans due to unsound investments in real estate during the so-called economic bubble. In other words, there were few cheerful issues. The public, which finally became unhappy with the Murayama administration's incompetence, began to seek the LDP's return to power, even though the LDP itself had recently been severely criticized by the public.

Prime Minister Murayama finally resigned in January 1996. The coalition government of the LDP and the Socialists continued, but it was now led by LDP politician Ryutaro Hashimoto. The public waited anxiously to see whether this would be the first stage of a new period of LDP rule or if Japan would utilize its experience of the past few years to develop a system permitting the genuine alternation of parties in office. The coalition government of the LDP and the Socialists is relevant to the research contained in this book because the Diet passed, in May 1995, the Law to Promote Decentralization (referred to here as the Decentralization Law). This crucial law could affect local governments and their relationship to the central government, and it probably would not have passed if the LDP's one-party rule had continued. By the fall of 1996, two midterm reports related to the law had been published. Their contents include proposals for radical decentralization.

The debate regarding local government reforms, which led to the Decentralization Law, began when local government issues were placed on the agenda of administrative reform in the early 1980s. The Second Provisional Administrative Reform Commission (Daini Rinchō) was an advisory committee formed to make proposals on administrative reform. Its orientation was neo-liberal, and it was supposed to enact the Japanese counterpart to the administrative reforms carried out by Prime Minister Margaret Thatcher in Great Britain and President Ronald Reagan in the United States. Yasuhiro Nakasone and other reform-minded 
LDP Diet members played key roles in the political process of Japan's administrative reforms.

The Daini Rinchō's reforms affected local governments in many ways: one reform, for example, reduced the conditional subsidies given by the central ministries to local governments. In addition, an important feature of the Daini Rinchō was that it provided a forum where politicians and bureaucrats from Tokyo and from the localities could debate issues concerning the central-local relationship. Although the Daini Rinchö's legal term of existence ended in 1983, problems involving local government continued to be a central concern of the First, Second, and Third Administrative Reform Promotion Commissions, all of which worked on administrative change. Of the four subcommittees of the third commission, one was specifically assigned to address local government systems. Hosokawa, who later became prime minister, was then the governor of Kumamoto prefecture, and he served as one of the leaders of this subcommittee.

The local government subcommittee proposed many governmental reforms, and in 1994, under the Hosokawa administration, these were approved at a cabinet meeting in a document entitled "Regarding the Policy of Promoting Future Administrative Reform." Based on this cabinet decision, a subcommittee on decentralization was created within the Administrative Reform Promotion Office, which itself was under the authority of the cabinet. Next, based on the proposals of the subcommittee on decentralization, the cabinet approved the "General Policy Regarding the Promotion of Decentralization" on December 25, 1994, and it prepared plans for promoting the decentralization of political authority. As mentioned above, the Decentralization Law was passed by the Diet in 1995, under the Murayama administration. Based on this law, the Decentralization Promotion Committee was attached to the prime minister's office, and it began holding sessions preparatory to the drafting of a new reform plan for decentralization.

Two conclusions may be drawn from all this. One is that the Decentralization Law is a product of the current period of political turmoil, which has continued since the breakdown of the LDP's long-standing one-party rule. The other is that decentralization is slowly but steadily being promoted. As expressed in Tip. O'Neill's favorite phrase, "All politics is local politics," many interests are involved in the relationship between the central government and local electoral districts, and this means that the debate over local government reform can proceed only in increments. 
The Decentralization Promotion Committee is supposed to produce a report within five years. Yet many people may question whether Japan's local governmental system, including central-local relations, will really change much as a result of the Decentralization Law. I believe that reforms will indeed be implemented. However, the reforms are likely only to mitigate, not eliminate, the type of central government involvement in local affairs referred to in this book as vertical administrative control. Furthermore, I think it probable that the local government pressures on the center, which I call horizontal, or lateral, political competition, will also persist. In other words, I believe that the models presented in this book will continue to be relevant despite the changes currently under way.

There are at least two reasons why decentralization is attracting so much attention in Japan today. The first is that Japan is currently undergoing a period of political transformation. During periods of transformation, local government systems tend to attract attention in Japan because local government is inevitably involved in any major administrative change. So much responsibility is already delegated to local governments that any administration reform must affect central-local relations. The structure of political confrontation, which consisted of political cleavages rooted in the cold war, has disappeared, and the main issue being contested now is whether to have a large or small government. The resolution of this issue will depend to a great extent on how the government handles the whole problem of decentralization.

The second reason decentralization is salient is that the volume of activity of Japan's local governments, as measured by their expenditures, is large. In the general account the expenditures of the Japanese government total roughly Iro billion yen (I.I billion dollars), of which more than two-thirds is spent by local authorities. Proposals regarding the size of government or the level of government activity, both of which are measured largely in terms of expenditure, therefore have a direct impact on the issue of decentralization. Although decentralization reforms have been taken up repeatedly since World War II, all the earlier efforts, in the 1940s through the 1970s, were promoted by progressives and leftists. In contrast, the current effort reflects pressure from business and key economic groups to reduce the level of government activity. These groups stress "small government" and deregulation, and they see decentralization as one step toward the realization of a smaller government.

Reformers face the two challenges of easing regulations and reducing the level of government spending and activity. Realistically, what is likely 
to result from their efforts? One possibility (option A) is to carry out deregulation and reduce government activity simultaneously. This approach would curb central government regulations, loosen the control of local governments by the central government, and reduce the level of activity of both central and local governments. This sort of decentralization would be welcomed by business. Among the political parties, it is the ideal image of the state held by neo-liberals, who stand out among the leaders of the New Frontier Party. A second possibility (option B) is that the central government will deregulate and trim its size, while the activities of local governments will increase to even higher levels. This option could be said to entail the acceptance of a welfare "state" at the local level. Should these options both fail to be realized, the only other alternative (option $\mathrm{C}$ ) is to maintain the current welfare state without reducing regulations or the level of government activity. This would be the choice of the left wing of the LDP and of the Social-Democratic Party (the former Japan Socialist Party). It would also please municipal governments and central government ministries and agencies. They like the status quo.

In my view, option $A$ is probably not a viable option for Japan, where the average age of the population is increasing rapidly. As many people have predicted, government expenditures are bound to increase to cope with the aging population. Option B currently has the most vocal support. While its proponents would continuously implement deregulation at the center, they would be less likely to trim welfare activities. However, there is a strong possibility that the status quo (option $\mathrm{C}$ ) will be maintained, and that no substantial change will occur.

Finally, I would like to address the relationship between the models I use in the text and the orthodox understanding of local governmental systems in advanced economies. Ordinarily, local government systems may be classified into two types: the separationist model, which is found in the United States and Great Britain, and the integrationist model, which is prominent in continental Europe. Japan's local government system is similar to the integrationist local government systems found on the European continent. Originally, in fact, Japan modeled its modern local governmental system after those of Prussia and France. It is interesting to note that in integrationist states, it is common for movements to form that try to move things closer to the types of local government found in the United States and Great Britain. Such was the case in France, for instance, where a decentralization law was passed in 1985.

Japan's centralized legal system prescribes an integrationist system of local government, combined with some elements of the separationist 
model bequeathed to it by the postwar U.S. occupation authorities. Many of Japan's academics would clearly prefer a separationist model of local government, and the Japanese debate on local autonomy has been led by a desire for greater decentralization. Consequently, much research has highlighted what I call the vertical administrative control model, emphasizing excessive central control over local governments. But I see the intense relationship between central and local governments as having sprung from local political initiatives as well. In my observation, the Japanese version of the integrationist model has evolved by means of a long-standing and two-sided process of political and administrative interaction between center and locality.

Japan's recently enacted Decentralization Law is a significant but still limited move in the direction of a separationist model of local government. As suggested earlier, I doubt whether the eventual scope of Japan's current reform project will prove all-encompassing. The country's system of local government is likely to remain within the general boundaries of the integrationist model.

I would like to take this opportunity to express my most sincere gratitude to Betscy Scheiner and James White, whose joint translation of this work is of the highest order. I would also like to thank Matthew Santamaria for his invaluable assistance during the last stage of editing. 